\title{
Systematic review of tattoo-associated skin infection with rapidly growing mycobacteria and public health investigation of a cluster in Scotland, 2010
}

P D Conaglen (philip.conaglen@nhs.net) ${ }^{1}$, I F Laurenson ${ }^{2}$, A Sergeant ${ }^{3}$, S N Thorn ${ }^{4}$, A Rayner ${ }^{2}$, J Stevenson ${ }^{4}$

1. NHS Fife, Department of Public Health, Cameron House, Leven, United Kingdom

2. NHS Lothian, Scottish Mycobacteria Reference Laboratory, Royal Infirmary of Edinburgh, Edinburgh, United Kingdom

3. NHS Lothian, Department of Dermatology, Lauriston Building, Edinburgh, United Kingdom

4. NHS Lothian, Department of Public Health, Waverley Gate, Edinburgh, United Kingdom

Citation style for this article:

Conaglen PD, Laurenson IF, Sergeant A, Thorn SN, Rayner A, Stevenson J. Systematic review of tattoo-associated skin infection with rapidly growing mycobacteria and public health investigation of a cluster in Scotland, 2010. Euro Surveill. 2013;18(32):pii=20553. Available online: http://www.eurosurveillance.org/

ViewArticle.aspx?Articleld $=20553$

Article submitted on 06 July 2012 / published on 08 August 2013

Sporadic cases and outbreaks of tattoo-associated skin infection with rapidly growing mycobacteria have been reported although they often contain few details of public health investigations and have not previously been systematically collated. We present the details of the public health investigation of a cluster of cases, which occurred in Scotland in 2010. Investigation of the cluster involved case finding, environmental investigation of the tattoo studio and pathological and microbiological investigation of possible cases and tattoo ink. Mycobacterium chelonae was isolated from one case and three probable cases were identified. M. chelonae was grown from an opened bottle of ink sourced from the studio these cases had attended. In addition, in order to identify all published cases, we conducted a systematic review of all reported cases of tattoo-associated skin infection with rapidly growing mycobacteria. A total of 25 reports were identified, describing 71 confirmed and 71 probable cases. Mycobacteria were isolated in 71 cases and $M$. chelonae was cultured from 48 of these. The most frequently postulated cause of infection was the dilution of black ink with tap water. Reports of tattoo-associated rapidly growing mycobacterial skin infection are increasing in frequency. Interested agencies must work with the tattoo industry to reduce the risk of contamination during tattoo ink manufacture, distribution and application.

\section{Introduction}

Rapidly growing mycobacteria (RGM) are a non-tuberculous group of mycobacteria commonly found in the environment in water, soil and dust [1]. The incidence of human infection with RGM is poorly described [2] although an increasing literature of sporadic cases and outbreaks has established RGM as important opportunistic human pathogens in both immunocompromised and healthy individuals [3]. RGM can cause a wide variety of conditions including catheter infections, skin and soft tissue infection, respiratory, endocardial, meningeal or bone infection and disseminated disease $[2]$.

In recent years, tattooing has become increasingly popular [4]. Both the peer-reviewed and grey literature contain sporadic reports of cases and outbreaks of RGM skin infection associated with tattooing [5-29]. Contamination leading to such tattoo-associated infection could theoretically occur at any point, from manufacture of the tattoo ink or equipment to application of the tattoo in the studio or during aftercare of the tattoo by the recipient. Reports of this emerging condition often contain few details of the public health investigations into the potential points of contamination and these reports have not previously been systematically collated.

A recent report described the clinical investigation and treatment of the United Kingdom's (UK's) first confirmed case, and three probable cases, of tattoo-associated RGM skin infection, which occurred in Scotland in 2010 [23]. Full details of the clinical investigation and treatment of these cases can be found in the original report [23]. In brief, the presentation and findings were similar for all four patients: within two weeks of their most recent tattoo session, erythematous papular eruptions appeared, predominantly in the grey-shaded areas of their tattoos (Figure 1). Histopathology suggested an infectious aetiology in each case although the Scottish Mycobacteria Reference Laboratory only isolated an organism ( $M$. chelonae) from the skin biopsy of one of the four individuals. All four had received their tattoos from a single tattooist at the same tattoo studio in Edinburgh between August and September 2010. The four individuals demonstrated initial spontaneous improvement; all were lost to subsequent follow-up [23].

We present a detailed description of the public health investigation of this cluster of cases of tattoo-associated 


\section{FIGURE 1}

Lesions caused by tattoo-associated skin infection with rapidly growing mycobacteria from a cluster of one confirmed and three probable cases, Scotland, 2010

A

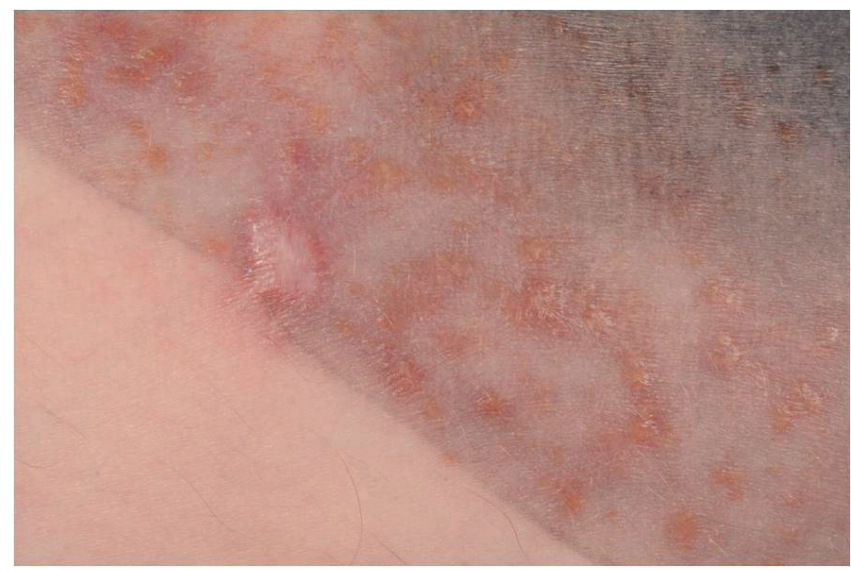

B

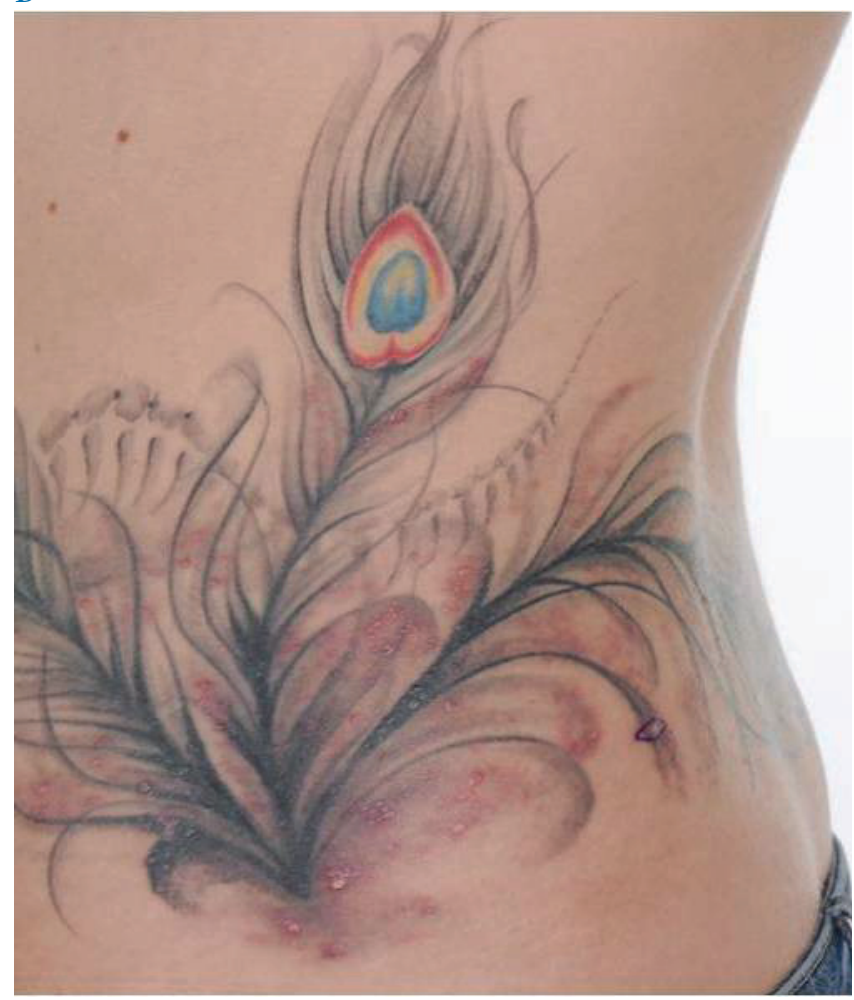

A Healing lesions localised in the grey-shaded areas of the confirmed case's tattoo. The skin biopsy site is also visible.

B Erythematous papular eruptions within the tattoo of one of the probable cases.
RGM skin infection in Scotland alongside a systematic review of all such cases reported in the literature.

\section{Methods}

Public health investigation into a cluster of tattoo-associated rapidly growing mycobacteria skin infection in Scotland

\section{Case definition}

Our initial case definition was any individual within the Lothian region of Scotland who, in the 12 months preceding the investigation, had RGM isolated from a recently tattooed area of skin. Recently tattooed was defined as tattooed in the 12 months before symptom onset. Patients from whom RGM were not isolated, but who had a clinical picture consistent with RGM skin infection in a recently tattooed area of skin, were defined as possible cases.

After initial case finding, the following final case definitions were agreed:

- confirmed case - a patient with clinical signs consistent with RGM skin infection (e.g. erythema, papules or pustules) in or around a recently tattooed area and from whom RGM were isolated;

- probable case - a patient with clinical signs from whom RGM were not isolated but who had an epidemiological link to a confirmed case (e.g. attended the same tattoo studio).

Case finding

The first case presented to his general practitioner (GP) in October 2010 and was referred to NHS Lothian, Department of Dermatology in January 2011. Having noticed other cases with a similar history, dermatology colleagues notified the local Public Health team in March 2011. Further cases were then sought by reviewing medical photography records for tattoo-associated lesions with similar characteristics between October 2010 and March 2011 and by searching the Scottish Mycobacteria Reference Laboratory records for cases of RGM infection associated with tattoos between January 2009 and March 2011.

An enhanced surveillance notification form was developed for local dermatologists to complete on seeing any tattoo-associated lesions. Organisations that might become aware of tattoo-related infections were contacted and asked to report any similar cases. These included: local authority liaison groups, the Scottish Skin Piercing Working Group, Health Protection Scotland, the former Health Protection Agency and the Health Protection Team at Christchurch Borough Council, Dorset (where the tattoo ink distributor was based).

Environmental investigation

The local tattoo licensing authority, City of Edinburgh Council, investigated the tattoo studio. Further to previous routine inspections, a visit was conducted that 
inspected the tattoo studio and its practices. A number of bottles of tattoo ink and diluent were obtained from both the tattoo studio (opened bottles) and directly from their distributor (unopened bottles) and sent for microbiological analysis. As the environmental investigation was conducted in March 2011, six to seven months after the tattoos were applied, the samples tested would not have been from ink used to tattoo the cases.

\section{Microbiological investigation}

Environmental samples were investigated by Edinburgh Scientific Services and the Scottish Mycobacteria Reference Laboratory in Edinburgh and also the former Health Protection Agency Food Water and Environmental Microbiology Laboratory in Southampton. Samples included tattoo ink, diluent and washings from an inkbottle nozzle.

\section{Literature review}

A literature search was conducted to identify all articles describing new confirmed cases of RGM skin infection associated with tattooing. The final case definitions listed above were used to classify confirmed and probable cases. Where a report also included details of probable cases, these were noted.

The initial search (last updated on 1 February 2013) used the controlled vocabulary terms 'Tattooing' AND 'Mycobacterium' within MEDLINE and Embase, combined with free-text searches for 'tattoo*' AND 'mycobacter"' in the same databases and in Web of Science. Searches were conducted using all available records within each database: up to November 2012 (MEDLINE) and December 2012 (Embase and Web of Science), without language restrictions. Duplicate records were discarded. Titles and abstracts were screened to identify articles that could confidently be excluded (see below). Full-text review of the remaining articles allowed inclusion/exclusion of publications, as per the criteria described below.

The reference lists of included publications were visually scanned for any further relevant titles. A Google Scholar search was conducted on 2 February 2013 for 'Tattoo mycobacter' with no language restrictions, using the inclusion/exclusion criteria described below. The title and preview text of each result on the first 20 pages of Google Scholar search results were visually scanned, to identify further cases from the grey literature.

The inclusion criteria were that the report contained at least one confirmed case of RGM skin infection - i.e. a patient with consistent clinical signs (see above), in or around a recently tattooed area (tattoo applied within 12 months of presentation, if stated), from whom RGM were isolated.

Reports were excluded if they did not contain a confirmed case, if they were review articles that only described previously published cases or if they were preliminary reports (e.g. conference abstracts) that were later published in full (e.g. a peer-reviewed article). Where necessary, authors were contacted to confirm such duplication. To reduce the burden of full-text retrieval and review, records were excluded if initial review of the title and abstract clearly identified a report containing only non-RGM infection (e.g. M. tuberculosis), a report containing only non-infectious cases (e.g. those with sarcoidosis) or a non-clinical study.

\section{Results}

Public health investigation into a cluster of tattoo-associated rapidly growing mycobacteria skin infection in Scotland

\section{Case finding}

As reported by Sergeant et al. [23], four cases were identified who met the case definition (one confirmed case and three possible cases). Neither enhanced surveillance nor awareness-raising exercises with other agencies led to the identification of any further cases. Analysis of six months of consent forms from the tattoo studio identified that they tattooed a mean of 133 clients per month. The four cases who attended this studio over two months thus represented 3\% (95\% confidence interval (Cl): 1-8) of the clients who would have attended the studio during this period.

\section{Ink and diluent samples}

Edinburgh Scientific Services conducted microbiological analyses on samples from four opened bottles of tattoo ink from the studio (two black and two grey), which identified Cupriavidus pauculus in the sample from one bottle of grey ink. Like M. chelonae, C. pauculus is a common environmental organism found, among other places, in tap water and is seldom isolated from clinical samples [30]. While this finding was unlikely to have any clinical relevance, it indicated that this opened bottle was not sterile. The opened bottle of grey ink that had produced this sample was retrieved from the studio along with a further two opened bottles of the same brand of ink and one opened bottle of diluent of the same brand. The studio had no unopened bottles of this brand. Samples from these four opened bottles were sent to the Scottish Mycobacteria Reference Laboratory, who subsequently isolated $M$. chelonae from the bottle sample that had originally grown $C$. pauculus. No microorganisms were identified in samples from the other three bottles.

In an attempt to identify the likely source of contamination, four unopened bottles of ink were obtained from the UK-based distributor, which supplied the studio with this American brand of ink. Samples were sent to the respective local authority laboratories and to the Scottish Mycobacteria Reference Laboratory. No 


\section{FIGURE 2}

Flow chart showing the selection of articles in the literature review to identify new cases of tattoo-associated skin infection with rapidly growing mycobacteria
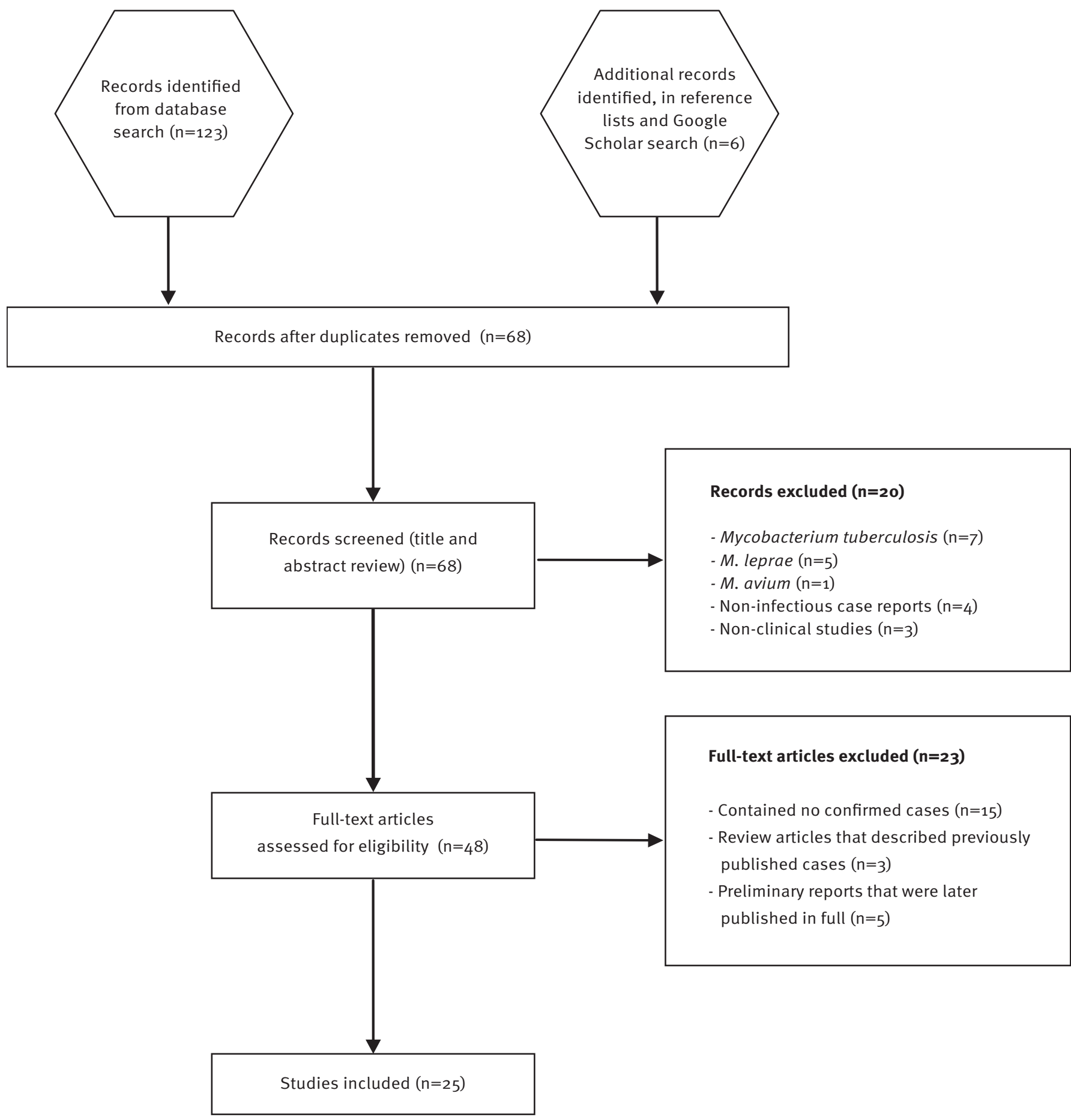
organisms were identified from any of the unopened bottles of ink from the distributor.

\section{Environmental investigation}

The tattoo studio's practices, premises and equipment all met local authority licensing requirements on both the investigative visit and during previous routine inspections. Specifically, the studio used ready-touse inks that bore an indication of durability (or 'use before' date). Their grey inks were purchased premixed and the tattoo artist stated that he had not diluted them with tap water in the studio. Tattoos were applied using aliquots of ink decanted into small single-use sterile pots.

Some UK distributors of tattoo inks are known to have their products sterilised by industrial gamma irradiation after import. The distributor that supplied this studio with the brand of ink under investigation did not.

\section{Control measures}

The tattoo studio voluntarily agreed to remove this brand of ink from use while the investigation was ongoing. An alert letter, detailing the brand and batch of ink was sent to all tattoo studios in the Lothian region, recommending it be withdrawn from use as a precaution. The UK distributor that supplied this brand of ink to the studio was also informed.

\section{Investigation outcome}

At the conclusion of our investigation, we had identified one confirmed case. While no microorganism was isolated from the three possible cases, the combination of clinical, pathological and epidemiological similarities was highly suggestive of a small cluster and these three cases were reclassified as probable cases. The exact source of the contamination was not identified.

\section{Literature review}

A flow chart of the selection of articles in the literature review can be seen in Figure 2. Our MEDLINE and Embase search identified 62 unique publications after the removal of 61 duplicate records. Title and abstract screening allowed the exclusion of 20 reports that did not meet inclusion criteria. Review of the titles of articles in the references of the remaining 42 articles identified two further reports and a Google Scholar search identified an additional four. From these 48 articles, 15 were excluded which contained no confirmed cases; three were excluded as review articles which described previously published cases and five were excluded as preliminary reports, which were later published in full. Interested readers may wish to note the research letter by Kluger et al. (which was excluded from this review as it contains no confirmed cases) as it gives a thorough account of a probable outbreak [31]. The report of an outbreak of seven cases in Germany by Hamsch et al. was included as, in two of the cases, DNA of an atypical mycobacterium that had not previously been described was detected by polymerase chain reaction $(P C R)$ - it bore features of $M$. haemophilum [14].
We identified a total of 25 reports that describe new cases of tattoo-associated RGM skin infection. These are summarised in the Table. The literature review identified the report of an outbreak in Rochester in New York State, United States, published by Kennedy et al. in August 2012 [24]. This outbreak was also summarised in an article in the Centers for Disease Control and Prevention (CDC) Morbidity and Mortality Weekly Report, which provided preliminary descriptions of four further clusters (not published elsewhere) that were identified as part of a subsequent, national investigation [25]. For the purposes of this review, the Kennedy et al. report was selected for the Rochester cases (as it contains full details) and the CDC article was selected as a separate single report of the remaining four clusters (with the Rochester cases excluded, to avoid duplication).

The 25 reports analysed, from 11 countries, described a total of 142 cases ( 71 confirmed and 71 probable cases). Three of the reports described infections following the application of 'permanent make-up' [14-16]. The techniques used for this cosmetic form of tattooing are broadly similar to conventional tattooing although the pigment tends to be applied more superficially $[14,32]$.

The number of published cases by year of publication is shown (Figure 3). In the six years following the first reported case in 2003, there were only three reports of such infections. However, the last three years (20102012) have seen a large rise both in the number of annual reports and in cumulative count of cases.

There are many similarities in the clinical presentation of reported cases, with descriptions tending to include erythema, nodules, papules or pustules usually confined to or around the tattooed areas. With several months of antibiotic treatment, outcomes tended to be good. The reports of Goldman, Rodriguez-Blanco, Hamsch and Sergeant describe a total of 10 cases who had resolution of symptoms without antimicrobials $[11,13,14,23]$. Notably one case series associated with permanent make-up appeared to have more complicated clinical presentation and worse outcomes [15].

RGM can be difficult to culture and mycobacteria were isolated from only 71 of the 142 reported cases. In 48 of these 71 cases, $M$. chelonae was identified. Some cases were on antimicrobials at the time of biopsy, which may account for the negative cultures. Other species less commonly found were M. haemophilum (12 cases), M. abscessus (6 cases), M. chelonael abscessus group (1 case), M. immunogenum (1 case), $M$. fortuitum (1 case) and unspecified mycobacteria (3 cases) (note: both $M$. chelonae and $M$. abscessus were isolated from one case). These RGM have varying pathogenicity and in vitro antimicrobial susceptibilities. It is unclear which treatments are optimal but decisions may be guided by in vitro susceptibility testing [33]. M. abscessus is often multiply resistant and reports of 
Characteristics of all previously published confirmed or probable cases of tattoo-associated skin infection with rapidly growing mycobacteria from the first published case in May 2003 to December 2012 (n=142)

\begin{tabular}{|c|c|c|c|c|c|}
\hline $\begin{array}{l}\text { First author, } \\
\text { publication year, } \\
\text { (location of cases) }^{\text {a }} \\
\text { [source] }\end{array}$ & $\begin{array}{l}\text { Number } \\
\text { of cases: } \\
\text { confirmed } \\
\text { (probable) }\end{array}$ & $\begin{array}{l}\text { Organisms } \\
\text { identified } \\
\text { (number of } \\
\text { cases) }\end{array}$ & Characteristics & Outcome & $\begin{array}{l}\text { Postulated source of } \\
\text { infection }\end{array}$ \\
\hline $\begin{array}{l}\text { Wolf, } \\
\text { May 2003, } \\
\text { (Tel Aviv, Israel) [5] }\end{array}$ & $1(0)$ & $\begin{array}{c}\text { Atypical } \\
\text { mycobacteria } \\
\text { (1) }\end{array}$ & $\begin{array}{l}\text { Tattoo had dark-blue outline } \\
\text { with green and yellow } \\
\text { colouring. Photograph of the } \\
\text { lesion shows spread beyond } \\
\text { tattoo borders. }\end{array}$ & $\begin{array}{l}\text { Patient refused treatment. } \\
\text { Nodules persisted. }\end{array}$ & Not postulated. \\
\hline $\begin{array}{l}\text { Sungkanuparph, } \\
\text { Sep 2003, Bangkok, } \\
\text { Thailand [6] }\end{array}$ & $1(0)$ & $\begin{array}{c}\text { Mycobacterium } \\
\text { chelonae/ } \\
\text { abscessus } \\
\text { group (1) }\end{array}$ & One nodule on a tattoo. & $\begin{array}{c}\text { Treated with excision } \\
\text { and sulfamethoxazole/ } \\
\text { trimethoprim. No relapse } 15 \\
\text { months post-treatment. }\end{array}$ & Not postulated. \\
\hline $\begin{array}{l}\text { Preda, } \\
\text { Mar 2009, Sydney, } \\
\text { Australia [7] }\end{array}$ & $1(0)$ & $\begin{array}{l}\text { M. chelonae } \\
\text { (1) }\end{array}$ & $\begin{array}{l}\text { Single artist using the same } \\
\text { ink over } 2 \text { months of serial } \\
\text { extensive tattooing to thigh } \\
\text { and arm. }\end{array}$ & $\begin{array}{l}\text { Substantial improvement } \\
\text { after } 4 \text { months of } \\
\text { clarithromycin and } \\
\text { moxifloxacin treatment. } \\
\text { Nodularity remained but } \\
\text { repeat biopsy grew no } \\
\text { mycobacteria. }\end{array}$ & $\begin{array}{l}\text { M. chelonae sourced } \\
\text { to a tattoo ink bottle } \\
\text { mixed using an } \\
\text { industrial bolt that } \\
\text { was left in situ. }\end{array}$ \\
\hline $\begin{array}{l}\text { Drage, } \\
\text { Mar 2010, Rochester, } \\
\text { MN, United States [8] }\end{array}$ & $3(3)$ & $\begin{array}{l}\text { M. chelonae } \\
\text { (3) }\end{array}$ & $\begin{array}{l}\text { Single artist in a single } \\
\text { establishment. Lesions } \\
\text { evolved within } 1-2 \text { weeks in } \\
\text { grey areas of tattoos (black } \\
\text { ink diluted with water). } \\
\text { Black areas not affected. } \\
\text { Median time to diagnosis of } \\
\text { 17.6 weeks (range: } 10-22.5 \\
\text { weeks). }\end{array}$ & $\begin{array}{l}\text { One patient lost } \\
\text { to follow-up. Five } \\
\text { patients improved with } \\
\text { clarithromycin (one } \\
\text { preceded by minocycline) } \\
\text { or azithromycin. All who } \\
\text { completed therapy had no } \\
\text { recurrence. }\end{array}$ & $\begin{array}{l}\text { Use of non-sterile } \\
\text { water to form grey } \\
\text { wash. The grey } \\
\text { wash used for these } \\
\text { patients had been } \\
\text { discarded. Other inks } \\
\text { tested negative. }\end{array}$ \\
\hline $\begin{array}{l}\text { Lollis, } \\
\text { Jul 2010, } \\
\text { San Antonio, TX, } \\
\text { United States } \\
\text { [9] }\end{array}$ & $1(10)$ & $\begin{array}{l}\text { M. abscessus } \\
\text { and } \\
\text { M. chelonae } \\
\text { (1) }\end{array}$ & $\begin{array}{l}\text { Single artist in a single } \\
\text { establishment. Erythematous, } \\
\text { papular eruptions in grey } \\
\text { areas of tattoos developed } \\
\text { 4-14 days after tattooing. } \\
\text { One patient also developed } \\
\text { polyarteritis syndrome. }\end{array}$ & $\begin{array}{l}\text { Three patients were } \\
\text { lost to follow-up. At 5-6 } \\
\text { months, two cases (one } \\
\text { on hydrocortisone cream } \\
\text { and doxycycline, one on } \\
\text { unspecified oral antibiotics) } \\
\text { completely resolved but two } \\
\text { (who received a variety of } \\
\text { different oral and or topical } \\
\text { treatments) had a persistent } \\
\text { rash. No further follow-up } \\
\text { reported. }\end{array}$ & $\begin{array}{l}\text { M. abscessus and } \\
\text { M. chelonae isolated } \\
\text { from the grey ink } \\
\text { used in all } 11 \text { cases. } \\
\text { Tattoo artist reported } \\
\text { there had been some } \\
\text { leakage into the } \\
\text { shipping container } \\
\text { that held these } \\
\text { bottles. }\end{array}$ \\
\hline $\begin{array}{l}\text { Bechara, } \\
\text { Aug 2010, } \\
\text { Paris, France [10] }\end{array}$ & $1(0)$ & $\begin{array}{l}\text { M. abscessus } \\
\text { (1) }\end{array}$ & $\begin{array}{l}\text { Onset of lesions } 10 \text { days post } \\
\text { tattoo. }\end{array}$ & $\begin{array}{l}\text { Complete healing after } \\
\text { initial treatment with } \\
\text { pristinamycin followed } \\
\text { by minocycline then } \\
\text { clarithromycin. No relapse at } \\
\text { 4-month follow-up. }\end{array}$ & $\begin{array}{l}\text { Grey ink, obtained by } \\
\text { dilution of a coloured } \\
\text { powder with tap } \\
\text { water, probably } \\
\text { responsible. }\end{array}$ \\
\hline $\begin{array}{l}\text { Goldman, } \\
\text { Oct 2010, } \\
\text { Le Havre, France [11] }\end{array}$ & $13(35)$ & $\begin{array}{l}\text { M. chelonae } \\
\text { (13) }\end{array}$ & $\begin{array}{c}\text { Two artists. All lesions in grey } \\
\text { areas of tattoo. }\end{array}$ & $\begin{array}{l}41 \text { patients successfully } \\
\text { treated with clarithromycin } \\
\text { (10 also had tobramycin). } \\
\text { The other seven were } \\
\text { not initially given } \\
\text { antibiotics: lesions healed } \\
\text { spontaneously in six } \\
\text { patients. }\end{array}$ & $\begin{array}{l}\text { Diluted black ink } \\
\text { (diluted with saline, } \\
\text { serum or tap water). } \\
\text { Also syringes rinsed } \\
\text { with tap water. }\end{array}$ \\
\hline $\begin{array}{l}\text { Ricciardo, } \\
\text { Nov 2010 (Perth, } \\
\text { Australia) } \\
{[12]}\end{array}$ & $1(1)$ & $\begin{array}{l}\text { M. abscessus } \\
\text { (1) }\end{array}$ & $\begin{array}{l}\text { Lesions confined to grey } \\
\text { pigment areas. }\end{array}$ & $\begin{array}{l}\text { After a variety of pre- } \\
\text { diagnosis treatments, } \\
\text { lesions improved } \\
\text { with minocycline and } \\
\text { clarithromycin. Patient } \\
\text { ceased treatment early } \\
\text { as flatmate with similar } \\
\text { symptoms remained well } \\
\text { with no treatment. }\end{array}$ & $\begin{array}{l}\text { Tap or non-sterile } \\
\text { water used to dilute } \\
\text { black ink. }\end{array}$ \\
\hline
\end{tabular}

CDC: United States Centers for Disease Control and Prevention.

a Where location of cases is not provided in the article, first author location is given here in parentheses.

b The five clusters described by the CDC included the investigation of inks manufactured by four companies (A-D).

c The report [25] contains the preliminary details of five clusters in the United States; the Rochester, NY, cluster described in full by Kennedy et al. [24] and the four clusters listed by State. Seattle and King County, WA, had two discrete clusters, denoted as Clusters A and B. 
Characteristics of all previously published confirmed or probable cases of tattoo-associated skin infection with rapidly growing mycobacteria from the first published case in May 2003 to December 2012 (n=142)

\begin{tabular}{|c|c|c|c|c|c|}
\hline $\begin{array}{l}\text { First author, } \\
\text { publication year, } \\
\text { (location of } \\
\text { cases) }^{\mathrm{a}} \text {, [source] }\end{array}$ & $\begin{array}{l}\text { Number } \\
\text { of cases: } \\
\text { confirmed } \\
\text { (probable) }\end{array}$ & $\begin{array}{l}\text { Organisms } \\
\text { identified } \\
\text { (number of } \\
\text { cases) }\end{array}$ & Characteristics & Outcome & $\begin{array}{l}\text { Postulated source of } \\
\text { infection }\end{array}$ \\
\hline $\begin{array}{l}\text { Rodriguez-Blanco, } \\
\text { Jan 2011, } \\
\text { (La Coruña, Spain) } \\
\text { [13] }\end{array}$ & $2(5)$ & $\begin{array}{l}\text { M. chelonae } \\
\text { (2) }\end{array}$ & $\begin{array}{c}\text { Lesions restricted to grey } \\
\text { areas. Onset } 3-30 \text { days after } \\
\text { tattooing. }\end{array}$ & $\begin{array}{l}\text { Two patients lost to follow-up. } \\
\text { Four had a good clinical } \\
\text { response with clarithromycin. } \\
\text { One refused treatment but } \\
\text { reported lesions had resolved } \\
\text { completely on telephone } \\
\text { follow-up. }\end{array}$ & $\begin{array}{l}\text { Tap water may have } \\
\text { been used to wash } \\
\text { the containers used } \\
\text { to mix inks. }\end{array}$ \\
\hline $\begin{array}{l}\text { Hamsch, } \\
\text { Jan 2011, } \\
\text { (Heidelberg, } \\
\text { Germany) } \\
{[14]}\end{array}$ & $2(5)$ & $\begin{array}{l}\text { Undefined } \\
\text { mycobacteria } \\
\text { with features of } \\
\text { M. haemophilum } \\
\text { (2) }\end{array}$ & $\begin{array}{l}\text { Single artist using a dark- } \\
\text { brown ink. Granulomatous } \\
\text { purulent skin reactions } \\
\text { in areas around eyebrow } \\
\text { permanent make-up } \\
\text { application. Lesion onset } \\
\text { days to weeks. }\end{array}$ & $\begin{array}{l}\text { Three patients improved with } \\
\text { ethambutol, clarithromycin } \\
\text { and rifampicin. Lesions } \\
\text { healed completely in one } \\
\text { patient without treatment. }\end{array}$ & $\begin{array}{l}\text { The dark-brown } \\
\text { ink was found to } \\
\text { be contaminated } \\
\text { with a multitude of } \\
\text { bacteria including } \\
\text { M. lentiflavum and } \\
\text { Ralstonia pickettii. }\end{array}$ \\
\hline $\begin{array}{l}\text { Giulieri, } \\
\text { Feb 2011, } \\
\text { (Lausanne, } \\
\text { Switzerland) [15] }\end{array}$ & $10(2)$ & $\begin{array}{l}\text { M. haemophilum } \\
\text { (10) }\end{array}$ & $\begin{array}{l}\text { Single freelance artist. } \\
\text { Red papules or pustules, } \\
\text { or erythematous plaque } \\
\text { over eyebrows with } \\
\text { lymphadenopathy after } \\
\text { permanent make-up } \\
\text { application. Eight patients } \\
\text { with abscesses, in seven } \\
\text { of these patients, the } \\
\text { abscesses became fistulae. }\end{array}$ & $\begin{array}{l}\text { Treatment with } \\
\text { clarithromycin, ciprofloxacin } \\
\text { and either rifabutin or } \\
\text { rifampicin was commenced } \\
\text { but often poorly tolerated. } \\
\text { Only two patients responded } \\
\text { to antibiotics and surgery was } \\
\text { required in nine cases. }\end{array}$ & $\begin{array}{l}\text { Six of } 18 \text { inks tested } \\
\text { were positive for } \\
\text { M. haemophilum. } \\
\text { Authors postulated } \\
\text { tap-water } \\
\text { contamination of ink. }\end{array}$ \\
\hline $\begin{array}{l}\text { Wollina, } \\
\text { Feb 2011, } \\
\text { (Dresden, } \\
\text { Germany) } \\
{[16]}\end{array}$ & $1(0)$ & $\begin{array}{c}\text { M. haemophilum } \\
\text { (1) }\end{array}$ & $\begin{array}{l}\text { Multiple tense subcutaneous } \\
\text { nodules and cysts along } \\
\text { right eyebrow } 8 \text { weeks after } \\
\text { eyebrow permanent makeup } \\
\text { application in South Asia. }\end{array}$ & $\begin{array}{l}\text { Rapid and almost complete } \\
\text { response to antibiotic } \\
\text { therapy with clarithromycin, } \\
\text { ciprofloxacin and rifampicin. }\end{array}$ & Not postulated. \\
\hline $\begin{array}{l}\text { Kappel, } \\
\text { Apr 2011, } \\
\text { (Los Angeles, CA, } \\
\text { United States) } \\
\text { [17] }\end{array}$ & $1(0)$ & $\begin{array}{l}\text { M. chelonae } \\
\text { (1) }\end{array}$ & $\begin{array}{l}\text { Tender erythematous } \\
\text { plaques and pustules } \\
\text { confined to the grey areas } \\
\text { within tattoos. Appeared } 2 \\
\text { months after tattooing. }\end{array}$ & $\begin{array}{l}\text { After a poor response } \\
\text { to doxycycline, use } \\
\text { of clarithromycin and } \\
\text { levofloxacin lead to } \\
\text { substantial improvement. }\end{array}$ & Not postulated. \\
\hline $\begin{array}{l}\text { Mitchell, } \\
\text { Apr 2011, (Chapel } \\
\text { Hill, NC, United } \\
\text { States) [18] } \\
\text { (1) }\end{array}$ & $1(0)$ & $\begin{array}{c}\text { M. } \\
\text { immunogenum } \\
\text { (1) }\end{array}$ & $\begin{array}{l}\text { Erythematous painful } \\
\text { papules and nodules mostly } \\
\text { within tattoo borders. }\end{array}$ & $\begin{array}{l}\text { Doxycycline (stopped after } \\
\text { 10 days) and clarithromycin } \\
\text { given for } 9 \text { to } 12 \text { months. } \\
\text { Continued to improve. }\end{array}$ & $\begin{array}{l}\text { Possibility of } \\
\text { some form of fluid } \\
\text { reservoir (no further } \\
\text { details given). }\end{array}$ \\
\hline $\begin{array}{l}\text { Kay, } \\
\text { Sep 2011, } \\
\text { (Seattle, WA, } \\
\text { United States) [19] }\end{array}$ & $1(1)$ & $\begin{array}{c}\text { M. haemophilum } \\
\text { (1) }\end{array}$ & $\begin{array}{l}\text { The confirmed case had } \\
\text { erythematous nodules in } \\
\text { the region of the tattoo. The } \\
\text { probable case had a pustulo- } \\
\text { nodular skin infection } \\
\text { confined to shaded areas of } \\
\text { tattoo. }\end{array}$ & $\begin{array}{l}\text { The confirmed case } \\
\text { had no response to } \\
\text { numerous pre-diagnosis } \\
\text { antibiotics. A course of } \\
\text { rifampicin, ciprofloxacin } \\
\text { and clarithromycin led } \\
\text { to improvement and } 3 \\
\text { months after discontinuing } \\
\text { antibiotics, the lesions had } \\
\text { healed. }\end{array}$ & $\begin{array}{l}\text { Tap water used in } \\
\text { a rinse solution } \\
\text { applied during and } \\
\text { after tattooing and } \\
\text { to dilute ink for } \\
\text { shading. }\end{array}$ \\
\hline $\begin{array}{l}\text { Binić, } \\
\text { Dec 2011, } \\
\text { (Kragujevac, } \\
\text { Serbia) } \\
{[20]}\end{array}$ & $2(0)$ & $\begin{array}{l}\text { M. chelonae } \\
\text { (2) }\end{array}$ & $\begin{array}{c}\text { Pruritic, red lichenoid } \\
\text { papules and plaques with } \\
\text { scales mostly in grey areas. } \\
\text { Three other clients from the } \\
\text { same establishment had } \\
\text { similar reactions but refused } \\
\text { assessment. }\end{array}$ & $\begin{array}{l}\text { Neither patient responded } \\
\text { to various pre-diagnosis } \\
\text { oral and topical agents. } \\
\text { The } M \text {. chelonae isolated in } \\
\text { both cases was susceptible } \\
\text { to clarithromycin although } \\
\text { neither treatment nor } \\
\text { outcome are stated. }\end{array}$ & $\begin{array}{l}\text { Tap water used to } \\
\text { make grey wash from } \\
\text { black pigment. }\end{array}$ \\
\hline
\end{tabular}

CDC: United States Centers for Disease Control and Prevention.

a Where location of cases is not provided in the article, first author location is given here in parentheses.

b The five clusters described by the CDC included the investigation of inks manufactured by four companies (A-D).

c The report [25] contains the preliminary details of five clusters in the United States; the Rochester, NY, cluster described in full by Kennedy et al. [24] and the four clusters listed by State. Seattle and King County, WA, had two discrete clusters, denoted as Clusters A and B. 
Characteristics of all previously published confirmed or probable cases of tattoo-associated skin infection with rapidly growing mycobacteria from the first published case in May 2003 to December 2012 (n=142)

\begin{tabular}{|c|c|c|c|c|c|}
\hline $\begin{array}{l}\text { First author, } \\
\text { publication year, } \\
\text { (location of cases) }^{a} \text {, } \\
\text { [source] }\end{array}$ & $\begin{array}{l}\text { Number } \\
\text { of cases: } \\
\text { confirmed } \\
\text { (probable) }\end{array}$ & $\begin{array}{l}\text { Organisms } \\
\text { identified } \\
\text { (number of } \\
\text { cases) }\end{array}$ & Characteristics & Outcome & $\begin{array}{l}\text { Postulated source of } \\
\text { infection }\end{array}$ \\
\hline $\begin{array}{l}\text { Winthrop, } \\
\text { Jun 2012, Portland, } \\
\text { OR, United States } \\
\text { [21] }\end{array}$ & $1(0)$ & $\begin{array}{l}\text { M. chelonae } \\
\text { (1) }\end{array}$ & $\begin{array}{l}\text { Itchy, violaceous papules } \\
\text { in black and grey areas of } \\
\text { tattoo about } 2 \text { weeks after } \\
\text { tattooing. }\end{array}$ & $\begin{array}{l}\text { All lesions completely resolved } \\
\text { after } 3 \text { months of azithromycin, } \\
\text { linezolid and vitamin B6. }\end{array}$ & Not postulated. \\
\hline $\begin{array}{l}\text { Sergeant, } \\
\text { Jul 2012, Edinburgh, } \\
\text { United Kingdom [23] }\end{array}$ & $1(3)$ & $\begin{array}{l}\text { M. chelonae } \\
\text { (1) }\end{array}$ & $\begin{array}{l}\text { Single artist. Dusky, } \\
\text { erythematous papules } \\
\text { some with scales in grey } \\
\text { tattooed areas. }\end{array}$ & $\begin{array}{l}\text { Following failure of pre- } \\
\text { diagnosis treatment with } \\
\text { topical and oral agents, the } \\
\text { eruptions in all cases later } \\
\text { improved spontaneously. } \\
\text { Two cases were also given } \\
\text { clarithromycin for } 6 \text { months. }\end{array}$ & $\begin{array}{c}\text { Growth of } \\
\text { microorganisms in } \\
\text { an opened bottle of } \\
\text { ink demonstrated } \\
\text { the potential for } \\
\text { environmental } \\
\text { contamination, } \\
\text { although this was } \\
\text { not the same ink } \\
\text { used for the cases. }\end{array}$ \\
\hline $\begin{array}{l}\text { Kennedy, } \\
\text { Aug 2012, Rochester, } \\
\text { NY, United States } \\
{[24]} \\
\text { See also }[25]^{\mathrm{c}}\end{array}$ & $14(5)$ & $\begin{array}{l}\text { M. chelonae } \\
(14)\end{array}$ & $\begin{array}{l}\text { Single artist. All cases } \\
\text { tattooed with ink from } \\
\text { Company } A^{b} \text {. Persistent, } \\
\text { raised erythematous rash } \\
\text { in grey areas within } 3 \\
\text { weeks of tattoo. }\end{array}$ & $\begin{array}{l}\text { Of the } 19 \text { patients, } 18 \text { were } \\
\text { treated with macrolides } \\
\text { with later addition of, or } \\
\text { switch to, doxycycline. All } 18 \\
\text { treated patients improved. } \\
\text { Antimicrobial susceptibility } \\
\text { studies were conducted in two } \\
\text { cases; microorganisms in both } \\
\text { these cases were sensitive to } \\
\text { clarithromycin and doxycycline. }\end{array}$ & $\begin{array}{l}\text { M. chelonae with } \\
\text { indistinguishable } \\
\text { pulsed-field gel } \\
\text { electrophoresis } \\
\text { pattern found in } \\
\text { unopened bottle } \\
\text { of ink (a grey wash } \\
\text { hand blended by the } \\
\text { manufacturer). }\end{array}$ \\
\hline $\begin{array}{l}\text { CDC, Aug 2012, } \\
\text { Seattle and King } \\
\text { County, WA, United } \\
\text { States: } \\
\text { Cluster B } \\
{[25]^{c}}\end{array}$ & $2(0)$ & $\begin{array}{l}\text { M. chelonae } \\
\text { (2) }\end{array}$ & $\begin{array}{c}\text { Cases were tattooed with } \\
\text { grey ink from Company } \\
\text { Cb. Note: there were also } \\
\text { two possible cases who } \\
\text { did not meet our case } \\
\text { definition. }\end{array}$ & Not stated. & $\begin{array}{l}\text { Sample from } \\
\text { opened bottle of } \\
\text { Company } C \text { ink } \\
\text { grew } M \text {. chelonae } \\
\text { but pulsed-field } \\
\text { gel electrophoresis } \\
\text { patterns suggested } \\
\text { it was unrelated to } \\
\text { the isolate that was } \\
\text { available from one } \\
\text { of the cases in this } \\
\text { cluster. }\end{array}$ \\
\hline
\end{tabular}

CDC: United States Centers for Disease Control and Prevention.

a Where location of cases is not provided in the article, first author location is given here in parentheses.

b The five clusters described by the CDC included the investigation of inks manufactured by four companies (A-D).

- The report [25] contains the preliminary details of five clusters in the United States; the Rochester, NY, cluster described in full by Kennedy et al. [24] and the four clusters listed by State. Seattle and King County, WA, had two discrete clusters, denoted as Clusters A and B. 
Characteristics of all previously published confirmed or probable cases of tattoo-associated skin infection with rapidly growing mycobacteria from the first published case in May 2003 to December 2012 (n=142)

\begin{tabular}{|c|c|c|c|c|c|}
\hline $\begin{array}{l}\text { First author, } \\
\text { publication year, } \\
\text { (location of }^{\text {cases) }} \text {, [source] }\end{array}$ & $\begin{array}{l}\text { Number } \\
\text { of cases: } \\
\text { confirmed } \\
\text { (probable) }\end{array}$ & $\begin{array}{l}\text { Organisms } \\
\text { identified } \\
\text { (number of } \\
\text { cases) }\end{array}$ & Characteristics & Outcome & $\begin{array}{l}\text { Postulated source of } \\
\text { infection }\end{array}$ \\
\hline $\begin{array}{l}\text { CDC, Aug 2012, } \\
\text { lowa, United } \\
\text { States } \\
{[25]^{c}}\end{array}$ & $2(0)$ & $\begin{array}{l}\text { M. chelonae } \\
\text { (2) }\end{array}$ & $\begin{array}{c}\text { Cases were tattooed with black } \\
\text { ink from Company } \mathrm{C}^{\mathrm{b}} \text {. Clinical } \\
\text { isolates from both cases were } \\
\text { indistinguishable by pulsed-field } \\
\text { gel electrophoresis from the } \\
\text { available clinical isolate from } \\
\text { the Seattle and King County, WA } \\
\text { Cluster B above. }\end{array}$ & Not stated. & Not postulated. \\
\hline $\begin{array}{l}\text { CDC, Aug 2012, } \\
\text { Colorado, United } \\
\text { States } \\
{[25]^{c}}\end{array}$ & $1(0)$ & $\begin{array}{l}\text { M. chelonae } \\
\text { (1) }\end{array}$ & $\begin{array}{l}\text { Tattooed with black ink from } \\
\text { Company } D^{b} \text {. }\end{array}$ & Not stated. & $\begin{array}{l}\text { Distilled or reverse- } \\
\text { osmosis water used } \\
\text { to dilute ink and } \\
\text { rinse needles (when } \\
\text { switching ink for } \\
\text { the same client). Ink } \\
\text { labelled as drawing } \\
\text { ink and specified that } \\
\text { it was not suitable for } \\
\text { tattooing. }\end{array}$ \\
\hline $\begin{array}{l}\text { Curcó, Nov } 2012 \\
\text { (Barcelona, } \\
\text { Spain) [26] }\end{array}$ & $1(1)$ & $\begin{array}{l}\text { M. chelonae } \\
\text { (1) }\end{array}$ & $\begin{array}{l}\text { Single artist. One patient had } \\
\text { papulopustules, another had } \\
\text { a } 1 \mathrm{~cm} \text { diameter erythematous } \\
\text { plaque with pustules. Both had } \\
\text { lesions confined to grey area of } \\
\text { tattoos } 2 \text { weeks and } 5 \text { days after } \\
\text { application respectively. }\end{array}$ & $\begin{array}{l}\text { Both had initial unsuccessful } \\
\text { treatment with topical } \\
\text { corticosteroids and } \\
\text { antibiotics. Lesions resolved } \\
\text { after } 3 \text { months and less than } \\
1 \text { month of clarithromycin } \\
\text { respectively. }\end{array}$ & $\begin{array}{c}\text { Tattoo artist created } \\
\text { a grey ink by mixing } \\
\text { black ink with rose } \\
\text { water from a local } \\
\text { pharmacy. }\end{array}$ \\
\hline $\begin{array}{l}\text { Shinohara, Dec } \\
2012 \text { (Seattle, } \\
\text { WA, United } \\
\text { States) [27] }\end{array}$ & $1(0)$ & $\begin{array}{l}\text { M. chelonae } \\
\text { (1) }\end{array}$ & $\begin{array}{c}\text { Burning, itching and } \\
\text { erythematous papules and } \\
\text { pustules noticed in grey areas of } \\
\text { tattoo } 3 \text { weeks after application } \\
\text { by professional mobile tattoo } \\
\text { service. }\end{array}$ & $\begin{array}{l}\text { Initial treatment with } \\
\text { oral clarithromycin and } \\
\text { levofloxacin. Susceptibility } \\
\text { testing showed resistance to } \\
\text { levofloxacin so changed to } \\
\text { clarithromycin monotherapy. } \\
\text { Lesions resolved completely } \\
\text { after } 4 \text { months of treatment. }\end{array}$ & Not postulated. \\
\hline $\begin{array}{l}\text { Schwartzman, } \\
\text { Dec } 2012 \text { (Los } \\
\text { Angeles, CA, } \\
\text { United States) } \\
\text { [28] }\end{array}$ & $1(0)$ & $\begin{array}{l}\text { M. chelonae } \\
\text { (1) }\end{array}$ & $\begin{array}{c}\text { Dramatic, diffuse blanching } \\
\text { erythema, tenderness and } \\
\text { warmth in both legs with a well- } \\
\text { described nodular rash. Signs } \\
\text { and symptoms progressed over } \\
4 \text { weeks. }\end{array}$ & $\begin{array}{l}\text { No improvement with } \\
\text { cefalexin treatment. After } \\
\text { diagnosis, the patient was } \\
\text { treated successfully with } 9 \\
\text { months of oral clarithromycin } \\
\text { and levofloxacin. }\end{array}$ & Not postulated. \\
\hline $\begin{array}{l}\text { Scott-Lang, Dec } \\
2012 \text { (Edinburgh, } \\
\text { United Kingdom) } \\
\text { [29] }\end{array}$ & $1(0)$ & $\begin{array}{l}\text { M. chelonae } \\
\text { (1) }\end{array}$ & $\begin{array}{l}\text { Rash in the grey area of a tattoo. } \\
\text { Similar rashes in other clients } \\
\text { who attended the same studio. }\end{array}$ & Not described. & $\begin{array}{l}\text { Tap water used to } \\
\text { dilute black ink and } \\
\text { rinse needles. }\end{array}$ \\
\hline
\end{tabular}

CDC: United States Centers for Disease Control and Prevention.

a Where location of cases is not provided in the article, first author location is given here in parentheses.

b The five clusters described by the CDC included the investigation of inks manufactured by four companies (A-D).

c The report [25] contains the preliminary details of five clusters in the United States; the Rochester, NY, cluster described in full by Kennedy et al. [24] and the four clusters listed by State. Seattle and King County, WA, had two discrete clusters, denoted as Clusters A and B. 


\section{FIGURE 3}

Published confirmed or probable cases of tattoo-associated rapidly growing mycobacteria skin infection by year of publication $(\mathrm{n}=142)$

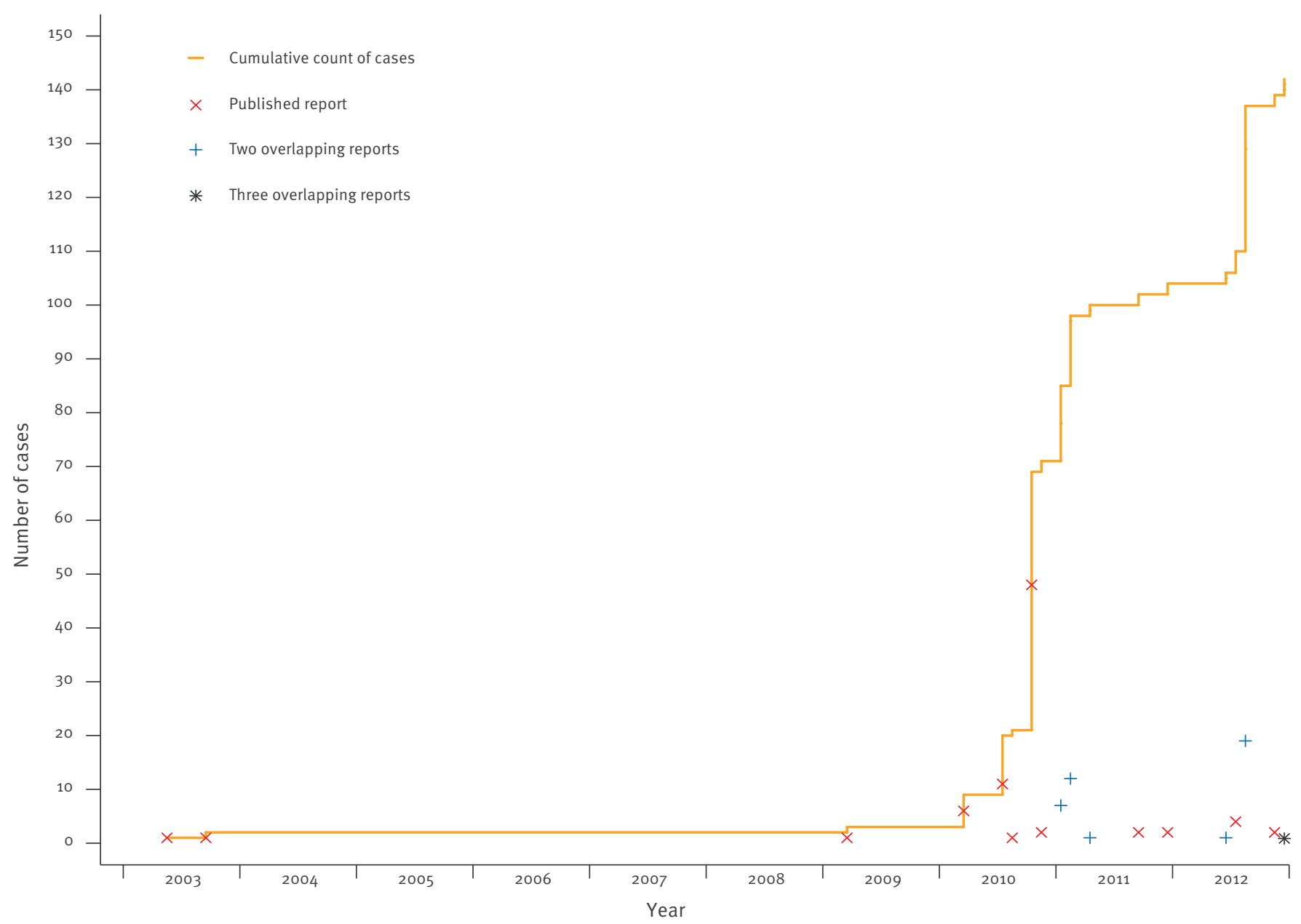

Presented by published report and as a cumulative count of cases. Reports published in the same month are depicted as overlapping reports.

in vitro and in vivo antagonism should alert us to possible complications of treatment [34].

In the literature to date, contamination occurring in the tattoo studio itself has been the main postulated or identified source of RGM skin infection. The most commonly proposed mechanism is the use of non-sterile tap water to either dilute black ink to a grey 'wash' or to clean tattooing equipment, as described in 11 of the reports identified in our review. The next most frequently proposed mechanism is some other form of environmental contamination of the tattoo ink (e.g. due to breached packaging or improper handling or storage of ink). A number of investigations identified RGM or other bacteria in opened bottles of tattoo ink. In such cases, it is impossible to verify where this contamination has occurred. Kennedy et al.'s 2012 paper has been the only report to date that has identified RGM in unopened bottles of tattoo ink, suggesting contamination during manufacture or distribution [24]. The indistinguishable pulsed-field gel electrophoresis patterns in the clinical isolates from clusters in lowa and Seattle and King County, WA, Cluster B, where cases had been tattooed with ink from the same manufacturer, would also suggest contamination occurred during manufacture or distribution [25]. Only one report described infection resulting from an amateur tattoo.

\section{Discussion}

We have summarised the characteristics of 25 published reports describing 142 confirmed and probable cases of RGM infection associated with tattooing. Estimates based on published cases are likely to underestimate the true incidence of this complication of tattooing. The frequency of published reports of this condition appears to have increased in recent years. This finding could be artefactual, driven by improved case identification (e.g. through raised clinical awareness or improvements in mycobacterial testing). Alternatively, the increase could indicate an emerging problem, potentially driven by changes in practices within the tattoo industry or the increasing popularity of tattoos. If the latter were true, one might also expect to observe increases in other tattoo-associated 
infections. Unfortunately, the limited literature available on this subject is divided. For example Urbanus et al. observed that while literature from the 1980 s and 1990 found an association between hepatitis B virus infection and tattooing, more recent literature rarely supports this finding [4]. Indeed a recent Dutch study by the same authors found no evidence of increased hepatitis $B$ or $C$ prevalence in people with multiple tattoos and/or piercings [32]. It should be noted that the Netherlands has implemented robust hygiene regulations around these procedures for a number of years, so this finding may reflect the success of national preventive measures for blood-borne virus transmission [32].

The most commonly postulated source of tattoo-associated RGM infection in the literature is contamination of tattoo ink or equipment with non-sterile water in the tattoo studio. However, the tattooist in the investigation of the Scottish cluster described and demonstrated tattooing procedures that included no such unsafe practice. In common with many similar investigations described in the literature, we were unable to obtain the actual bottles of ink used for the cases. The isolation of both $C$. pauculus and $M$. chelonae from an opened bottle of grey ink from the same studio some months later suggested contamination could have occurred in the tattoo studio. However, the ubiquitous nature of these microorganisms in the environment means that contamination during collection or processing of environmental samples remains a possibility.

Contamination during production or distribution of the ink is also a possibility. Our cluster investigation did not identify any further cases in the UK at the time, nor did we find any evidence of contamination in unopened ink samples sourced from the distributor. This was the best, albeit weak, evidence that we could pragmatically gather against contamination having occurred higher in the supply chain in our investigation.

Recent analyses of a wide range of commercially available tattoo inks demonstrated surprisingly high rates of bacterial contamination in both open and unopened ink bottles $[35,36]$. The most recent of these noted that $10 \%$ of unopened ink bottles tested were contaminated, $28 \%$ had inadequate physical sealing and a number made false claims of sterility [36]. These studies did not test specifically for RGM.

A search for 'tattoo ink' on the European Union Rapid Alert System for non-food dangerous products (RAPEX) website [37] identified five occurrences of tattoo inks being banned, recalled or withdrawn because of bacterial contamination since 2005 . None of these instances involved RGM, although it is possible that culture techniques appropriate for mycobacteria were not employed during testing. These occurrences are consistent with the high prevalence of bacterial contamination in tattoo inks, identified in the studies above. It was perhaps unsurprising that, in 2012, Kennedy et al. described the first reported outbreak in which RGM (indistinguishable from those in clinical samples by pulsed-field gel electrophoresis) were identified in unopened bottles of the same brand of premixed ink that was used for the tattoos [24].

Manufacturing requirements in Europe and the United States tend to treat tattoo inks as cosmetic substances, with much less stringent controls than for medical products that are injected $[36,38,39]$. Within Europe, recommendations have been produced that include a requirement of sterility for tattoo ink - for example, the European Council tattoo regulations [40]. However, few countries have adopted such regulations to date, although the existence of empirical data demonstrating high rates of tattoo ink contamination may help change this $[35,36]$.

The sterilisation of tattoo inks is not straightforward. Filter sterilisation would also remove the coloured particulates that give the ink its character. One alternative is to use industrial gamma-irradiation and we are aware of a number of tattoo suppliers in the UK that employ this approach. We have heard of anecdotal concerns regarding the potential for decomposition of ink constituents following irradiation but were unable to find any published evidence of this phenomenon, nor of the safety or effectiveness of this technique.

Our public health investigation could not confirm the point of contamination in the Scottish cluster. Analyses of inks on the market, combined with recent clusters in the United States, suggest that quality control measures for tattoo inks clearly need to be improved to ensure a sterile product is produced. However, the identification of unsafe practice in tattoo studios in many reports suggests that efforts also need to continue to be focused here. Any such interventions must balance the benefits of stricter controls with the risks of alienating the tattoo industry or increasing tattoo prices as these, in turn, could increase the prevalence of illegal tattooing with potentially grave public health consequences.

\section{Acknowledgements}

The authors would like to thank Carole-Ann Wright and Colin Sibbald from the City of Edinburgh Council, Louise Joyner from Christchurch Borough Council, Dorset, and the staff at both the Edinburgh Scientific Services and the Scottish Mycobacteria Reference Laboratory (SMRL) for their invaluable assistance with these investigations (SMRL laboratory work is carried out as part of the remit of the SMRL, funded through its contract with Health Protection Scotland and National Services Scotland). We would also like to thank Dr Alan Beswick from the Health and Safety Laboratory for his expert advice; and Martin Higgins from NHS Lothian, Dr David McAllister from the University of Edinburgh and Dr Catherine O'Connor from the Health Protection Agency for their incisive comments on the manuscript. Finally, we would like to thank the reviewers for their thorough and helpful scrutiny.

This review was not supported by external funding. 


\section{References}

1. De Groote MA, Huitt $\mathrm{G}$. Infections due to rapidly growing mycobacteria. Clin Infect Dis. 2006;42(12):1756-63. http:// dx.doi.org/10.1086/504381 PMid:16705584

2. Esteban J, Martin-de-Hijas NZ, Fernandez Al, Fernandez-Roblas $\mathrm{R}$, Gadea I. Epidemiology of infections due to nonpigmented rapidly growing mycobacteria diagnosed in an urban area. Eur J Clin Microbiol Infect Dis. 2008;27(10):951-7. http://dx.doi. org/10.1007/s10096-008-0521-7 PMid:18458972

3. Han XY. Seasonality of clinical isolation of rapidly growing mycobacteria. Epidemiol Infect. 2008;136(9):1188-91. http:// dx.doi.org/10.1017/S095026880700982X PMid:18005476 PMCid:PMC 2870912

4. Urbanus $A T$, van den Hoek A, Boonstra A, van Houdt $R$, de Bruijn LJ, Heijman T, et al. People with multiple tattoos and/or piercings are not at increased risk for HBV or HCV in the Netherlands. PLoS One. 2011;6(9):e24736. http:// dx.doi.org/10.1371/journal.pone.0024736 PMid:21935447 PMCid:PMC3173466

5. Wolf R, Wolf D. A tattooed butterfly as a vector of atypical mycobacteria. J Am Acad Dermatol. 2003;48(5 Suppl):S73-4. http://dx.doi.org/10.1067/mjd.2003.166 PMid:12734482

6. Sungkanuparph S, Sathapatayavongs B, Pracharktam R. Infections with rapidly growing mycobacteria: report of 20 cases. Int J Infect Dis. 2003;7(3):198-205. http://dx.doi. org/10.1016/S1201-9712(03)90052-X

7. Preda VA, Maley M, Sullivan IR. Mycobacterium chelonae infection in a tattoo site. Med J Aust. 2009;190(5):278-9. PMid:19296796

8. Drage LA, Ecker PM, Orenstein R, Phillips PK, Edson RS. An outbreak of Mycobacterium chelonae infections in tattoos. J Am Acad Dermatol. 2010;62(3):501-6. http://dx.doi.org/10.1016/j. jaad.2009.03.034 PMid:19733936

9. Lollis B, Kent R. AFRL-SA-BR-TP-2010-0001. Cluster of nontuberculous mycobacteria skin infections from tattoos. Brooks City-Base, TX: United States Air Force (USAF) School of Aerospace Medicine; 2010. [Accessed 10 Feb 2013]. Available from: http://www.dtic.mil/dtic/tr/fulltext/u2/a523390.pdf

10. Bechara C, Macheras E, Heym B, Pages A, Auffret N. Mycobacterium abscessus skin infection after tattooing: first case report and review of the literature. Dermatology. 2010;221(1):1-4. http://dx.doi.org/10.1159/000313974 PMid:20558973

11. Goldman J, Caron F, de Quatrebarbes J, Pestel-Caron M, Courville P, Doré MX, et al. Infections from tattooing. Outbreak of Mycobacterium chelonae in France. BMJ. 2010;341:C5483. http://dx.doi.org/10.1136/bmj.c5483 PMid:20978041

12. Ricciardo B, Weedon D, Butler G. Mycobacterium abscessus infection complicating a professional tattoo. Australas J Dermatol. 2010;51(4):287-9. http://dx.doi.org/10.1111/j.14400960.2010.00659.x PMid:21198529

13. Rodríguez-Blanco I, Fernández LC, Suárez-Pe-aranda JM, Pérez del Molino ML, Esteban J, Almagro M. Mycobacterium chelonae infection associated with tattoos. Acta Derm Venereol. 2011;91(1):61-2. PMid:21264454

14. Hamsch C, Hartschuh W, Enk A, Flux K. A Chinese tattoo paint as a vector of atypical mycobacteria-outbreak in 7 patients in Germany. Acta Derm Venereol. 2011;91(1):63-4. PMid:21103853

15. Giulieri S, Morisod B, Edney T, Odman M, Genné D, Malinverni $\mathrm{R}$, et al. Outbreak of Mycobacterium haemophilum infections after permanent makeup of the eyebrows. Clin Infect Dis. 2011;52(4):488-91. http://dx.doi.org/10.1093/cid/ciq191 PMid:21258102

16. Wollina U. Nodular skin reactions in eyebrow permanent makeup: two case reports and an infection by Mycobacterium haemophilum. J Cosmet Dermatol. 2011;10(3):235-9. http:// dx.doi.org/10.1111/j.1473-2165.2011.00564.x PMid:21896137

17. Kappel S, Cotliar J. Inoculation of Mycobacteria chelonae from a tattoo. J Am Acad Dermatol. 2011;64(5):998-9. http://dx.doi. org/10.1016/j.jaad.2009.08.029 PMid:21496711

18. Mitchell CB, Isenstein A, Burkhart CN, Groben P, Morrell DS. Infection with Mycobacterium immunogenum following a tattoo. J Am Acad Dermatol. 2011;64(5):e70-1. http://dx.doi. org/10.1016/j.jaad.2009.12.037 PMid:21496684

19. Kay MK, Perti TR, Duchin JS. Tattoo-associated Mycobacterium haemophilum skin infection in immunocompetent adult, 2009. Emerg Infect Dis. 2011;17(9):1734-6. http://dx.doi.org/10.3201/ eid1709.102011 PMid:21888807 PMCid:PMC3322073

20. Binić I, Janković A, Ljubenović M, Gligorijević J, Jančić S, Janković D. Mycobacterium chelonae infection due to black tattoo ink dilution. Am J Clin Dermatol. 2011;12(6):404-6. PMid:21797287
21. Winthrop KL, Varley CD, Sullivan A, Hopkins RS. Happy Buddha? Clin Infect Dis. 2012;54(11):1670-1. http://dx.doi. org/10.1093/cid/cir998 PMid:22573894

22. Suvanasuthi S, Wongpraparut C, Pattanaprichakul P, Bunyaratavej S. Mycobacterium fortuitum cutaneous infection from amateur tattoo. J Med Assoc Thai. 2012;95(6):834-7. PMid:22774631

23. Sergeant A, Conaglen P, Laurenson IF, Claxton P, Mathers ME, Kavanagh GM, et al. Mycobacterium chelonae infection: a complication of tattooing. Clin Exp Dermatol. 2013;38(2):1402. http://dx.doi.org/10.1111/j.1365-2230.2012.04421.x PMid:22831709

24. Kennedy BS, Bedard B, Younge M, Tuttle D, Ammerman E, Ricci J, et al. Outbreak of Mycobacterium chelonae infection associated with tattoo ink. N Engl J Med. 2012;367(11):1020-4. http://dx.doi.org/10.1056/NEJMoa1205114 PMid:22913660

25. Centers for Disease Control and Prevention (CDC). Tattooassociated nontuberculous mycobacterial skin infections - multiple states, 2011-2012. MMWR Morb Mortal Wkly Rep. 2012;61(33):653-6. PMid:22914227

26. Curcó N, Prat C, Tarroch X, Vives P. Cutaneous infection in a tattoo due to mycobacterium chelonae: a report of 2 cases and a review of the literature. Actas Dermosifiliogr. 2012;103(9):840-3. http://dx.doi.org/10.1016/j.ad.2012.01.019 PMid:22749366

27. Shinohara MM, Nguyen J, Gardner J, Rosenbach M, Elenitsas R. The histopathologic spectrum of decorative tattoo complications. J Cutan Pathol. 2012;39(12):1110-8. http:// dx.doi.org/10.1111/cup.12023 PMid:23046178

28. Schwartzman WA. Mycobacterium chelonae illnesses associated with tattoo ink. N Engl J Med. 2012;367(24):2356-7; author reply 2357-8. http://dx.doi.org/10.1056/NEJMc1212350 PMid:23234523

29. Scott-Lang VE, Sergeant A, Holme A. Mycobacteria introduced by tattoos. BMJ. 2012;345:e8331. http://dx.doi.org/10.1136/ bmj.e8331

30. Balada-Llasat J-M, Elkins C, Swyers L, Bannerman T, Pancholi P. Pseudo-outbreak of Cupriavidus pauculus infection at an outpatient clinic related to rinsing culturette swabs in tap water. I Clin Microbiol. 2010;48(7):2645-7. http://dx.doi.org/10.1128/JCM.01874-09 PMid:20444965 PMCid:PMC2897476

31. Kluger N, Muller C, Gral N. Atypical mycobacteria infection following tattooing: review of an outbreak in 8 patients in a French tattoo parlor. Arch Dermatol. 2008;144(7):941-2. http:// dx.doi.org/10.1001/archderm.144.7.941 PMid:18645149

32. Worp J, Boonstra A, Coutinho RA, van den Hoek JA. Tattooing, permanent makeup and piercing in Amsterdam; guidelines, legislation and monitoring. Euro Surveill. 2006;11(1):pii=591. Available from: http://www.eurosurveillance.org/ViewArticle. aspx?Articleld=591 PMid:16484732

33. Griffith DE, Aksamit T, Brown-Elliott BA, Catanzaro A, Daley C, Gordin F, et al. An official ATS/IDSA statement: diagnosis, treatment, and prevention of nontuberculous mycobacterial diseases. Am J Respir Crit Care Med. 2007;175(4):367-416. http://dx.doi.org/10.1164/rccm.200604-571ST PMid:17277290

34. Choi GE, Min KN, Won CJ, Jeon K, Shin SJ, Koh WJ. Activities of moxifloxacin in combination with macrolides against clinical isolates of Mycobacterium abscessus and Mycobacterium massiliense. Antimicrob Agents Chemother. 2012;56(7):354955. http://dx.doi.org/10.1128/AAC.00685-12 PMid:22564831 PMCid:PMC3393384

35. Baumgartner A, Gautsch S. Hygienic-microbiological quality of tattoo- and permanent make-up colours. J Verbrauch Lebensm. 2011;6(3):319-25. http://dx.doi.org/10.1007/ s00003-010-0636-5

36. Høgsberg T, Saunte DM, Frimodt-Moller N, Serup J. Microbial status and product labelling of 58 original tattoo inks. J Eur Acad Dermatol Venereol. 2013;27(1):73-80. http://dx.doi. org/10.1111/j.1468-3083.2011.04359.x PMid:22145628

37. European Commission (EC). The rapid alert system for non-food dangerous products (RAPEX). Brussels: EC. [Accessed 2 Jan 2012]. Available from: http://ec.europa.eu/consumers/safety/rapex/alerts/main/ index.cfm?event=main. search

38. United States Food and Drug Administration (FDA). Product information. Tattoos \& permanent makeup. Silver Spring, MD: FDA: 2000. [Accessed 10 Feb 2013]. Available from: http://www.fda.gov/cosmetics/productandingredientsafety/ productinformation/ucm108530.htm

39. LeBlanc P, Hollinger K, Klontz K. Tattoo ink-related infections-awareness, diagnosis, reporting, and prevention. N Engl J Med. 2012;367(11):985-7. http://dx.doi.org/10.1056/NEJMp1206063 PMid:22913662 
40. Council of Europe (COE) Committee of Ministers. Resolution

ResAP(2008)1 on requirements and criteria for the safety of tattoos and permanent make-up (superseding Resolution

ResAP(2003)2 on tattoos and permanent make-up). (Adopted by the Committee of Ministers on 20 February 2008 at the

1018th meeting of the Ministers' Deputies). Strasbourg: COE:

2008. [Accessed 10 Feb 2013]. Available from: https://wcd.coe.

int $/$ ViewDoc.jsp?id $=1254065 \&$ Site $=C M \& B$ ackColorlnternet $=C_{3}$

$\mathrm{C}_{3} \mathrm{C}_{3} \&$ BackColorlntranet $=\mathrm{EDB} 021 \&$ BackColorLogged $=\mathrm{F}_{5} \mathrm{D}_{3} 83$ 